\title{
Inhibition of Acinetobacter baumannii, Staphylococcus aureus and Pseudomonas aeruginosa biofilm formation with a class of TAGE-triazole conjugates ${ }^{\dagger}$
}

\author{
Robert W. Huigens III, Steven A. Rogers, Andrew T. Steinhauer and Christian Melander*
}

Received 13th October 2008, Accepted 20th November 2008

First published as an Advance Article on the web 12th January 2009

DOI: 10.1039/b817926c

A chemically diverse library of TAGE-triazole conjugates was synthesized utilizing click chemistry on the TAGE scaffold. This library of small molecules was screened for anti-biofilm activity and found to possess the ability of inhibiting biofilm formation against Acinetobacter baumannii, Staphylococcus aureus and Pseudomonas aeruginosa. One such compound in this library demonstrated the most potent inhibitory effect against Staphylococcus aureus biofilm formation that has been displayed by any

2-aminoimidazole derivative.

\section{Introduction}

Recent findings in biomedical research have revealed that biofilmmediated infections play a prominent role in infectious disease. ${ }^{1}$ Bacterial biofilms are defined as highly structured communities of microbial cells attached to a surface and encased in a protective matrix made primarily of polysaccharide material. ${ }^{2}$ Biofilm formation occurs when free-swimming planktonic cells collectively coordinate their behavior through a communication pathway involving signaling molecules, termed quorum sensing, resulting in their attachment to a surface and colonization..$^{3-5}$ Once a biofilm is established, these bacteria act as if they were a multicellular organism resulting in the virulent phenotypes associated with various biofilm-mediated diseases. Despite their prevalence, biofilm-associated infections have been a medical obstacle due to their increased resistance to conventional antibiotics as well as host immune responses. ${ }^{6}$

There have been relatively few small molecules identified that possess anti-biofilm activity, with anti-biofilm activity defined as modulating biofilm development through non-toxic mechanisms. Examples of compounds possessing anti-biofilm activity include derivatives of homoserine lactones, ${ }^{7}$ which are endogenous signaling molecules used by bacteria in quorum sensing, ${ }^{8,9}$ brominated furanones which are natural products isolated from the macroagla Delisea pulchra, ${ }^{10}$ as well as ursine triterpenes from the plant Diospyros dendo. ${ }^{11}$ Recently, Junker and Clardy reported the development of a high throughput screen revealing several small molecules capable of inhibiting Pseudomonas aeruginosa biofilms (Fig. 1). ${ }^{12}$

Our group has recently developed several novel libraries of 2aminoimidazole small molecules inspired by the marine alkaloids bromoageliferin 6 and oroidin 10. ${ }^{13-19}$ These natural products were previously reported to inhibit biofilm formation of the marine $\alpha$ protobacterium Rhodospirillum salexigens. ${ }^{20}$ TAGE and CAGE

North Carolina State University Chemistry Department, 2620 Yarborough Drive, Raleigh, North Carolina, 27695-8204, United States of America $\dagger$ Electronic supplementary information (ESI) available: Dose-response curves for biofilm inhibition; growth curves at $\mathrm{IC}_{50}$ value of biofilm inhibition; representative ${ }^{1} \mathrm{H}$ and ${ }^{13} \mathrm{C}$ NMR spectra. See DOI: $10.1039 / \mathrm{b} 817926 \mathrm{c}$

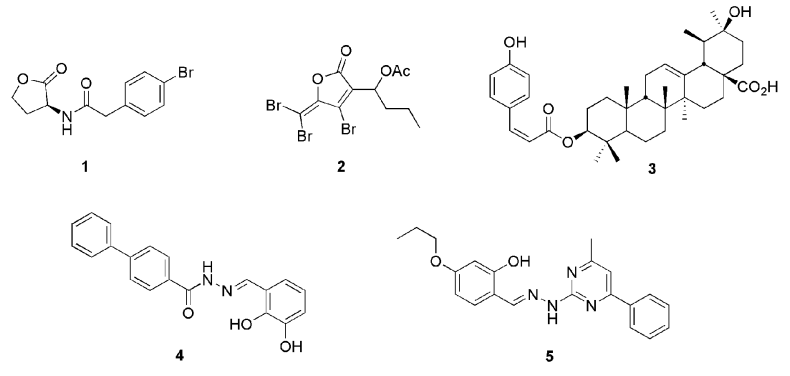

Fig. 1 Previously reported biofilm inhibitors.

were the first documented 2-aminoimidazoles with anti-biofilm activity against Pseudomonas aeruginosa biofilms (Fig. 2). ${ }^{13}$

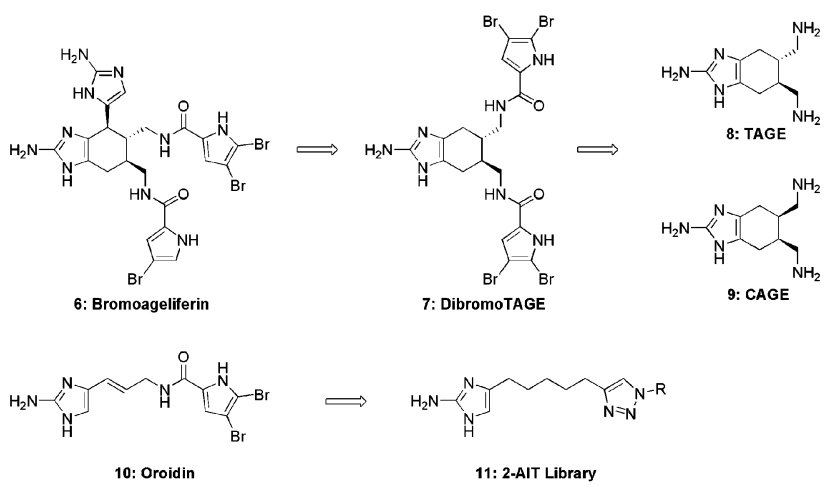

Fig. 2 Representative 2-aminoimidazoles derived from the marine natural products bromoageliferin $\mathbf{6}$ and oroidin $\mathbf{1 0}$.

Analogues of the structurally simpler alkaloid oroidin were also pursued to develop novel classes of small molecules with anti-biofilm activity. Recently, an oroidin inspired library was constructed utilizing click chemistry to generate a diverse library of 2-aminoimidazole/triazole conjugates (2-AIT). These compounds displayed the widest spectrum of anti-biofilm activity observed within the 2-aminoimidazole class (Fig. 2, 11). ${ }^{18}$

Based on the potent activity displayed by 2-AIT conjugates, we decided to explore if triazole incorporation within the TAGE scaffold would lead to compounds with enhanced anti-biofilm 
activity. To accomplish this goal, we postulated that epoxide $\mathbf{1 2}$ could be synthetically elaborated to AzidoTAGE 13 (Fig. 3). The appending azides were designed to serve as synthetic handles for derivatization using click chemistry to generate a TAGE-triazole library.
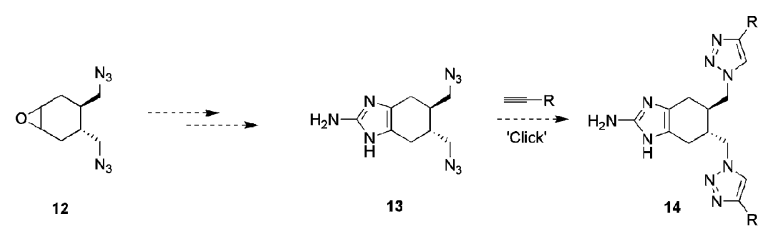

Fig. 3 Synthetic approach to the construction of a TAGE-triazole library from previously reported epoxide $\mathbf{1 2}$.

\section{Results and discussion}

\section{Synthesis of TAGE-triazole library}

The assembly of the TAGE-triazole library was initiated by refluxing epoxide $\mathbf{1 2}$ in a 1:1 mixture of aqueous ammonium hydroxide and methanol saturated with ammonia for 5.5 hours in a sealed tube (Scheme 1). Acid-base extraction yielded the pure aminoalcohol in 97\% yield. The resulting amine was then Bocprotected ( $99 \%$ yield) and further subjected to PDC oxidation to give Boc-protected $\alpha$-aminoketone $\mathbf{1 5}$ in $81 \%$ yield. The Bocgroup was then removed upon treatment with TFA followed by subsequent addition of $\mathrm{HCl}$ in methanol to effect counter ion exchange. This resulting $\alpha$-aminoketone $\cdot \mathrm{HCl}$ salt was then dissolved in water followed by the addition of cyanamide and the $\mathrm{pH}$ of the solution was adjusted to 4 . This reaction was heated to $95^{\circ} \mathrm{C}$ for 2.5 hours, delivering AzidoTAGE 13 in $79 \%$ yield over 2 steps as the $\mathrm{HCl}$ salt.

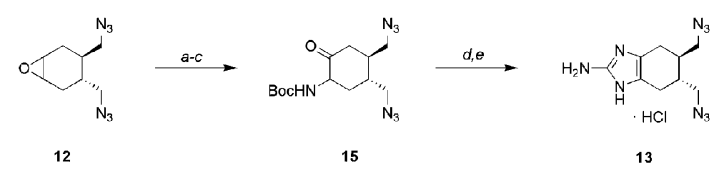

Scheme 1 Synthesis of AzidoTAGE 13. Reaction conditions: (a) $\mathrm{NH}_{4} \mathrm{OH}$, $\mathrm{H}_{2} \mathrm{O}, \mathrm{MeOH}\left(\mathrm{NH}_{3}\right)$, reflux, 97\% (b) $\mathrm{Boc}_{2} \mathrm{O}$, acetone, $\mathrm{H}_{2} \mathrm{O}, \mathrm{Na}_{2} \mathrm{CO}_{3}$, reflux, 99\% (c) PDC, DMF, room temp, $81 \%$ (d) TFA, $\mathrm{CH}_{2} \mathrm{Cl}_{2}, 0{ }^{\circ} \mathrm{C}$ to room temp (e) $\mathrm{NH}_{2} \mathrm{CN}, \mathrm{H}_{2} \mathrm{O}, \mathrm{pH} 4,95^{\circ} \mathrm{C}, 79 \%$.

Although this library was designed to combine the 1,2,3-triazole element of the 2-AIT library with the TAGE scaffold ${ }^{18}$ this new platform is chemically distinct from our previous approach to 2 AIT conjugates in that the azides are on the core TAGE scaffold bearing the 2-aminoimidazole. In the 2-AIT library, the terminal alkyne is on the core scaffold with the 2-aminoimidazole. This reversal in click partners allows easier access to a chemically diverse library since most of the azides of the 2-AIT library required synthesis from the corresponding alcohols. The majority of terminal alkynes in this study were commercially available. Alkynes that were not commercially available required only one step and were purified by recrystallization.

The click reaction was carried out in the presence of the $\mathrm{HCl}$ salt of AzidoTAGE 13. The click conditions we employed for this study relied on a 1:1:1 ratio of ethanol:water:dichloromethane, copper sulfate $(15-30 \mathrm{~mol} \%)$ and sodium ascorbate. ${ }^{18}$ These reactions were typically carried out overnight at room temperature (1624 hours). The alkynes chosen for this study vary from being structurally simple hydrocarbon chains to those decorated with brominated pyrrole rings. These TAGE-triazole small molecules provided the necessary diversity to attain a preliminary insight into the SAR of TAGE-triazole conjugates in the context of biofilm inhibition and dispersion. These conditions were shown to be general, allowing the construction of a chemically diverse 21membered TAGE-triazole library (Table 1). The TAGE-triazole library is composed of four series, which are classified according to the structural variation of the triazole moiety as the hydrocarbon chain series, cycloalkyl series, phenyl series and amide series.

\section{Biofilm inhibition studies}

The TAGE-triazole library was initially screened for anti-biofilm activity against Acinetobacter baumannii. A. baumannii is a Gramnegative bacterium recognized by the medical field for its role in nosocomial infections. Infections acquired from A. baumannii are difficult to treat because they are resistant to many antibiotics, such as penicillin, chloramphenicol and often aminoglycosides. ${ }^{21}$ This multidrug-resistance (MDR) is attributed to active drug efflux ability. A. baumannii elicits its pathogenicity through biofilmmediated virulence and tests positive in $25 \%$ of all hospital swabs in both the US and Europe. ${ }^{22,23}$

The TAGE-triazole library members were initially screened at $400 \mu \mathrm{M}$ to eliminate weakly active or inactive TAGE-triazole conjugates. Inhibition screens were run using PVC microtiter plates in a 96-well format. The inside of these wells serves as a surface for biofilm attachment and development during bacterial growth. The amount of biofilm that forms on the inside of these wells is quantified by using a crystal violet reporter assay. ${ }^{13}$ These values then serve as a point of comparison to identify lead biofilm inhibitors. This approach quickly eliminated six compounds that were not able to inhibit biofilm formation by $50 \%$ at $400 \mu \mathrm{M}$ (H5, C1, P2, A1, A2, A3). Dose-response curves were then generated for the remaining 15 compounds to determine their respective $\mathrm{IC}_{50}$ values (Table 2).

In the series of simple hydrocarbon chains we noted that the inhibitory activity was dependent on chain length and branching (Fig. 4). Using analogue $\mathbf{H 1}$ as our point of reference, extension of the hydrocarbon chain one methylene unit from butyl H1 to pentyl $\mathbf{H 2}$ increased inhibition activity significantly. The $\mathrm{IC}_{50}$ of $\mathbf{H 1}$ was measured as $161 \pm 25 \mu \mathrm{M}$, while $\mathbf{H 2}$ was $59.6 \pm$ $2.8 \mu \mathrm{M}$. Inhibition activity is increased again by extending the pentyl side chain (H2) to the hexyl chain (H3). The $\mathrm{IC}_{50}$ value of $\mathbf{H 3}$ was determined to be $51.7 \pm 4.7 \mu \mathrm{M}$. Extending the hydrocarbon chain one more methylene unit from $\mathbf{H 3}$ gave the heptyl derivative H4 which showed a decrease in activity $\left(\mathrm{IC}_{50}\right.$ value of $74.1 \pm$ $5.0 \mu \mathrm{M}$ ). Following this structural trend, the decyl side of $\mathbf{H 5}$ showed very weak inhibition activity with only $21 \%$ inhibition at $400 \mu \mathrm{M}$. Branching of the butyl side chain with the 3-methyl group of $\mathbf{H 6}$ increased the inhibition activity 3-fold compared to the parent butyl chain H1. This simple 3-methyl addition to the butyl chain gave an $\mathrm{IC}_{50}$ value of $57.5 \pm 12 \mu \mathrm{M}$. The $t$-butyl side chain of $\mathbf{H 7}$ resulted in a slight decrease of inhibition activity giving an $\mathrm{IC}_{50}$ value of $188 \pm 26 \mu \mathrm{M}$. 
Table 1 Synthesis of the TAGE-triazole library

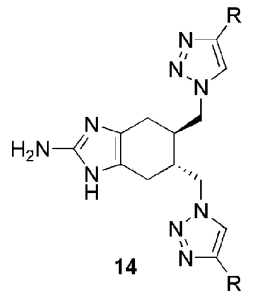

$\%$ Yield

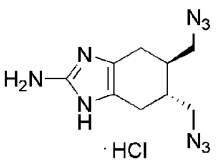

13
TAGE-triazole

Series and Terminal Alkyne

Hydrocarbon Series $(\mathbf{H})$ :

1-Hexyne

1-Heptyne

1-Octyne

1-Nonyne

1-Dodecyne

5-Methyl-1-hexyne

3,3-Dimethyl-1-butyne

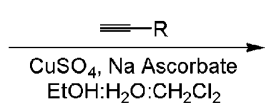

Cycloalkyl Series $(\mathbf{C})$

Cyclopropylacetylene

Cyclopentylacetylene

Cyclohexylacetylene

3-Cyclopentyl-1-propyne

3-Cyclohexyl-1-propyne EtOH: $\mathrm{H}_{2} \mathrm{O}: \mathrm{CH}_{2} \mathrm{Cl}_{2}$

Phenyl Series (P):

Phenylacetylene

4-Ethynylanisole

3-Phenyl-1-propyne

4-Phenyl-1-butyne

3-Phenoxy-1-propyne

Amide Series (A):

$N$-(Prop-2-ynyl)benzamide

$N$-(Prop-2-ynyl)-1 $H$-pyrrole-2-carboxyamide

4-Bromo- $N$-(prop-2-ynyl)- $1 H$-pyrrole-2-carboxyamide

4,5-Dibromo- $N$-(prop-2-ynyl)- $H$-pyrrole-2-carboxyamide

Table 2 Initial screen of the TAGE-triazole library for biofilm inhibition against Acinetobacter baumannii ATCC 19606

\begin{tabular}{lc}
\hline TAGE-triazole & $\%$ Inhibition at $400 \mu \mathrm{M}$ \\
\hline H1 & $83 \pm 3$ \\
H2 & $99 \pm 1$ \\
H3 & $96 \pm 2$ \\
H4 & $98 \pm 1$ \\
H5 & $21 \pm 1$ \\
H6 & $97 \pm 1$ \\
H7 & $76 \pm 9$ \\
C1 & $30 \pm 6$ \\
C2 & $98 \pm 1$ \\
C3 & $99 \pm 1$ \\
C4 & $99 \pm 1$ \\
C5 & $81 \pm 3$ \\
P1 & $70 \pm 7$ \\
P2 & $16 \pm 4$ \\
P3 & $77 \pm 4$ \\
P4 & $98 \pm 1$ \\
P5 & $91 \pm 1$ \\
A1 & $3 \pm 1$ \\
A2 & $7 \pm 2$ \\
A3 & $49 \pm 4$ \\
A4 & $84 \pm 4$ \\
\hline
\end{tabular}

The cycloalkyl series also provided structural insight into inhibiting A baumannii biofilm formation. We began by determining the activity of the cyclopentyl derivative $\mathbf{C 2}$ which gave an $\mathrm{IC}_{50}$ value of $79.5 \pm 9.5 \mu \mathrm{M}$. When a methylene linker was

\begin{tabular}{ll}
25 & H1 \\
27 & H2 \\
39 & H3 \\
32 & H4 \\
31 & H5 \\
64 & H6 \\
68 & H7 \\
& \\
27 & C1 \\
46 & C2 \\
21 & C3 \\
27 & C4 \\
35 & C5 \\
& \\
51 & P1 \\
47 & P2 \\
14 & P3 \\
37 & P4 \\
25 & P5 \\
40 & \\
55 & A1 \\
14 & A2 \\
26 & A3 \\
\hline
\end{tabular}
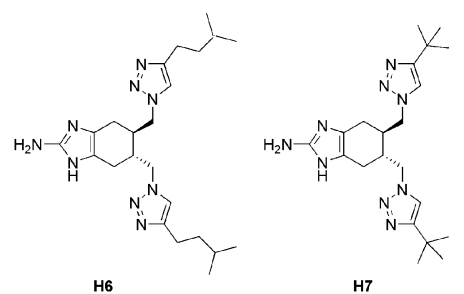

$H 1: n=3$
$H 2: n=4$

$H 3: n=5$
$H 4: n=6$

H4: $n=6$
H5: $n=7$

H6

H7

\begin{tabular}{cc}
\hline TAGE-triazole & $\mathrm{IC}_{50}(\mu \mathrm{M})$ \\
\hline $\mathrm{H} 3$ & $51.7 \pm 4.7$ \\
$\mathrm{H} 6$ & $57.5 \pm 12$ \\
$\mathrm{H} 2$ & $59.6 \pm 2.8$ \\
$\mathrm{H} 4$ & $74.1 \pm 5.0$ \\
$\mathrm{H} 1$ & $161 \pm 25$ \\
$\mathrm{H} 7$ & $188 \pm 26$ \\
$\mathrm{H} 5$ & - \\
\hline
\end{tabular}

Fig. 4 Structures and biofilm inhibition activity against $A$. baumannii of the TAGE-triazole hydrocarbon chain series.

inserted between the triazole and cyclopentyl ring to give $\mathbf{C 4}$ the activity was essentially identical, giving an $\mathrm{IC}_{50}$ value of $75.1 \pm$ $5.7 \mu \mathrm{M}$. Trading out a 5-membered ring for the 6-membered ring in C3 gave a slight increase in activity with a measured 
$\mathrm{IC}_{50}$ value of $63.9 \pm 5.7 \mu \mathrm{M}$. Placement of a methylene spacer between the triazole ring and the cyclohexyl ring (C5) greatly reduced inhibition activity as demonstrated by an $\mathrm{IC}_{50}$ value of $127 \pm 14 \mu \mathrm{M}$ (Fig. 5). Cyclopropyl derivative $\mathbf{C 1}$ demonstrated weak biofilm inhibition activity against $A$. baumannii, inhibiting $30 \%$ of biofilm formation at $400 \mu \mathrm{M}$.

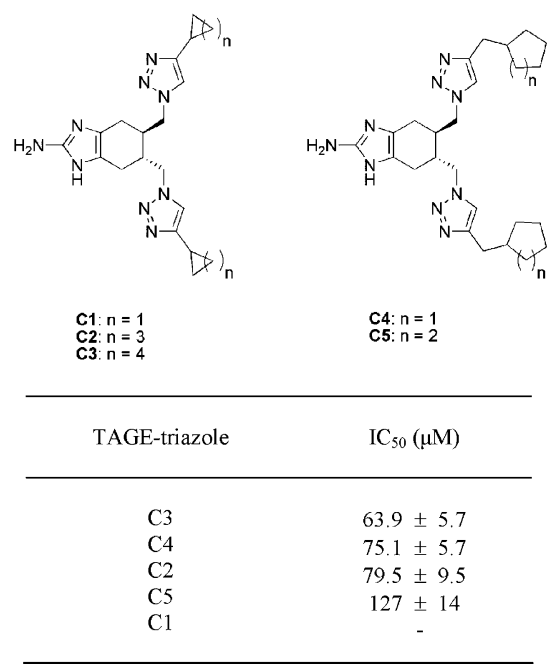

Fig. 5 Structures and biofilm inhibition activity against $A$. baumannii of the TAGE-triazole cycloalkyl series.

The third class of TAGE-triazoles was based on substituted phenyl derivatives. The phenyl ring derivative $\mathbf{P 1}$ gave an $\mathrm{IC}_{50}$ value of $120 \pm 29 \mu \mathrm{M}$ against $A$. baumannii biofilm formation. Changing the electronics of the phenyl ring was investigated by adding a 4-methoxy group to the phenyl ring giving P2. This greatly decreased the inhibition activity and only $16 \%$ biofilm inhibition was observed at $400 \mu \mathrm{M}$. Extending the phenyl ring out by adding the methylene unit in $\mathbf{P 3}$ also decreased the activity slightly $\left(\mathrm{IC}_{50}=165 \pm 12 \mu \mathrm{M}\right)$. However, extending the phenyl ring by two methylene units in $\mathbf{P 4}$ greatly increased the activity giving the best inhibitor in the phenyl ring series with an $\mathrm{IC}_{50}$ value of $61.5 \pm 10 \mu \mathrm{M}$. Substituting the second methylene unit from the triazole of this active structure with an oxygen atom in P5 decreased the activity from the lead ethyl spacer within this series by giving an $\mathrm{IC}_{50}$ value of $80.1 \pm 9.5 \mu \mathrm{M}$ (Fig. 6).

Within the amide series of the TAGE-triazole library, the only active member against $A$. baumannii biofilm formation was A4 (Fig. 7). The activity of this small molecule was surprising considering the importance of 2-aminoimidazole dibromopyrrole conjugates as biofilm modulators. ${ }^{14,16,17,19}$ The $\mathrm{IC}_{50}$ value for $\mathbf{A 4}$ was determined to be $48.8 \pm 8.6 \mu \mathrm{M}$. The other members of the amide series demonstrated weak inhibitory activity at $400 \mu \mathrm{M}$.

When comparing the relatively complex structure of $\mathbf{A 4}$ to a previous TAGE derivative, DibromoTAGE 7, the inhibition activity drops 3-fold when compared to the previously reported $\mathrm{IC}_{50}$ value of $15.5 \mu \mathrm{M}$ against $A$. baumannii. ${ }^{16}$ This drop in activity may be attributed to the unoptimized head-to-tail distance from the 2-aminoimidazole head to the dibromopyrrole tail in this structure. Previous studies in our labs have shown that the antibiofilm activity is dependent on the relative distance between the 2-aminoimidazole moiety and either dibromopyrrole or triazole heterocycles. ${ }^{17,18}$

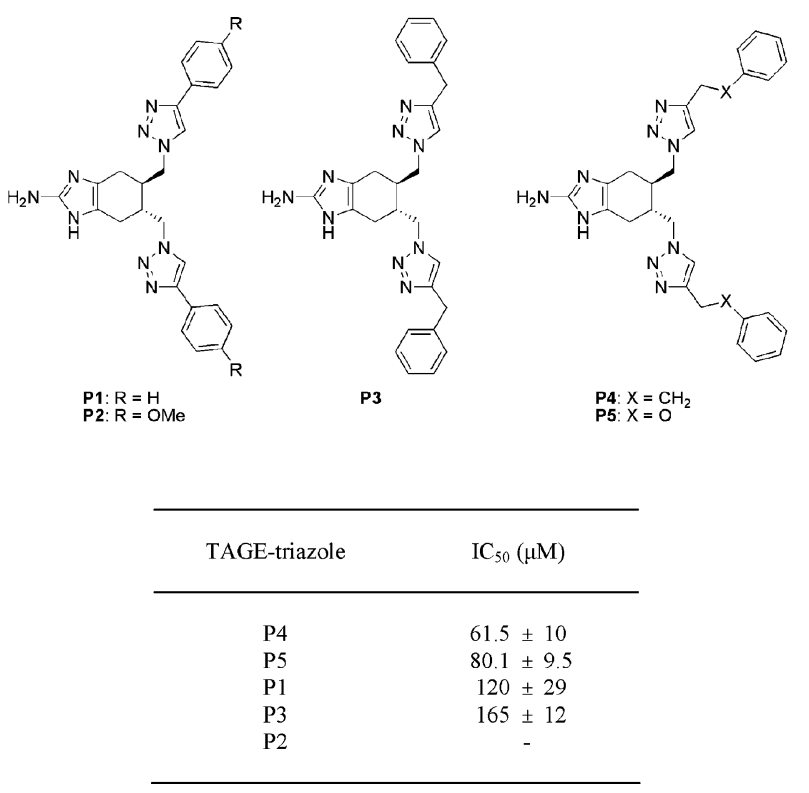

Fig. 6 Structures and biofilm inhibition activity against $A$. baumannii of the TAGE-triazole phenyl ring series.

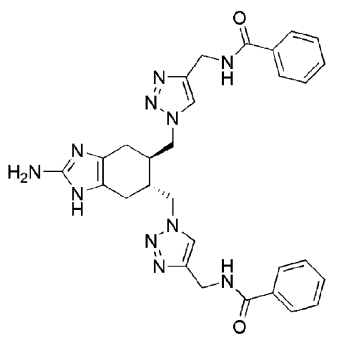

A1

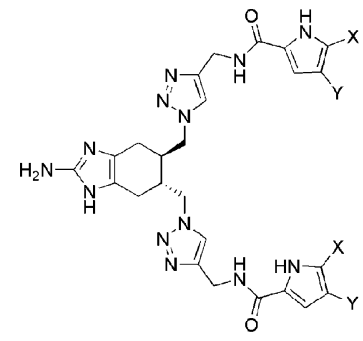

A2: $X, Y=H$ A3: $X=H, Y=B$

\begin{tabular}{cc} 
TAGE-triazole & $\mathrm{IC}_{50}(\mu \mathrm{M})$ \\
\hline $\mathrm{A} 4$ & $48.8 \pm 8.6$ \\
$\mathrm{~A} 1$ & - \\
$\mathrm{A} 2$ & - \\
$\mathrm{A} 3$ & -
\end{tabular}

Fig. 7 Structures and biofilm inhibition activity against $A$. baumannii of the TAGE-triazole amide series.

Each compound that was able to generate an $\mathrm{IC}_{50}$ value below $400 \mu \mathrm{M}$ against $A$. baumannii was tested against planktonic bacteria to determine if these small molecules elicited their effects through a toxic mechanism. These compounds were added to a test tube at the $\mathrm{IC}_{50}$ value and optical densities of the treated and untreated samples were monitored after 1, 3, 5, 7 and 24 hours. After 5 and 7 hours, some TAGE-triazole library members show a slight reduction in the bacterial growth of $A$. baumannii, indicating some bacterial static effects, however, after 24 hours, there was no reduction in the optical densities between treated and untreated planktonic growth.

The next opportunistic bacterium we investigated was Staphlyococcus aureus, a Gram-positive bacterium responsible for many 
Table 3 Initial screen for biofilm inhibition against Staphylococcus aureus ATCC 29213

\begin{tabular}{ll}
\hline TAGE-triazole & $\%$ Inhibition at $400 \mu \mathrm{M}$ \\
\hline H1 & $47 \pm 6$ \\
H2 & $22 \pm 7$ \\
H3 & $93 \pm 1$ \\
H4 & $98 \pm 1$ \\
H5 & No activity \\
H6 & $99 \pm 1$ \\
C1 & $95 \pm 1$ \\
C2 & No activity \\
C3 & $95 \pm 3$ \\
C4 & $71 \pm 5$ \\
C5 & $33 \pm 9$ \\
P1 & $76 \pm 8$ \\
P2 & $22 \pm 1$ \\
P3 & $95 \pm 4$ \\
P4 & $76 \pm 6$ \\
P5 & $97 \pm 2$ \\
A1 & $70 \pm 9$ \\
A2 & No activity \\
A3 & No activity \\
A4 & No activity \\
\hline
\end{tabular}

nosocomial infections. S. aureus is notorious for being multi-drug resistance against several classes of antibiotics (i.e. penicillins, aminoglycosides, glycopeptides). Methicillin-resistant Staphylococcus aureus (MRSA) and Vancomycin-resistant Staphylococcus aureus (VRSA) are two examples of strains that have developed resistance to conventional antibiotics. ${ }^{24}$ Given that $S$. aureus forms robust biofilms, we screened our TAGE-triazoles to identify possible inhibitors of biofilm formation. As with A. baumannii, we initially screened this library at $400 \mu \mathrm{M}$ (Table 3 ).

From this initial screen eight compounds (H3, H4, H6, H7, C2, P2, P4, A4) demonstrated greater than $90 \%$ inhibition and were further evaluated in inhibition screens. Four of the active TAGE-triazoles were from the hydrocarbon series, one from the cycloalkyl series, two from the phenyl ring series and one from the amide series (Fig. 8).

\begin{tabular}{ll}
\hline TAGE-triazole & IC $_{50}$ Value \\
& \\
\hline H3 & $270 \pm 15 \mu \mathrm{M}$ \\
$\mathrm{H} 4$ & $171 \pm 5 \mu \mathrm{M}$ \\
$\mathrm{H} 6$ & $224 \pm 15 \mu \mathrm{M}$ \\
$\mathrm{H} 7$ & $220 \pm 22 \mu \mathrm{M}$ \\
$\mathrm{C} 2$ & $122 \pm 16 \mu \mathrm{M}$ \\
$\mathrm{P} 2$ & $118 \pm 13 \mu \mathrm{M}$ \\
$\mathrm{P} 4$ & $222 \pm 7 \mu \mathrm{M}$ \\
$\mathrm{A} 4$ & $141 \pm 28 \mathrm{nM}$ \\
\hline
\end{tabular}

Fig. $8 \mathrm{IC}_{50}$ values for the active TAGE-triazoles against Staphylococcus aureus.

Interestingly P2, which showed only $16 \pm 4 \%$ inhibition at $400 \mu \mathrm{M}$ against $A$. baumannii, gave $95 \pm 4 \%$ inhibition at $400 \mu \mathrm{M}$ against $S$. aureus biofilm formation and upon further evaluation gave an $\mathrm{IC}_{50}$ value of $118 \pm 13 \mu \mathrm{M}$. However, when tested for bactericidal activity, growth curves with $\mathbf{P 2}$ indicated a reduction in cellular density of about $25 \%$ at the 24 hour time point although there was no reduction during exponential growth. Although several of these compounds were shown to effect bacterial growth
TAGE-triazoles H7, C2, P4 and A4 showed no reduction in bacterial density in the growth curves.

TAGE-triazole A4 demonstrated the most potent inhibitory effect of any 2-aminoimidazole derivative thus far against $S$. aureus with an $\mathrm{IC}_{50}$ value of $141 \pm 28 \mathrm{nM}$. We felt that this small molecule would be very effective in inhibition screens since DibromoTAGE 7 was reported to give good inhibition against $S$. aureus $\left(\mathrm{IC}_{50}\right.$ value of $14.0 \mu \mathrm{M}),{ }^{16}$ but some of this activity was occurring by inhibition of bacterial growth. However, the insertion of a triazole moiety adjacent to the dibrominated pyrrole carboxyamide not only greatly increases activity (100-fold), but also gives an actual biofilm inhibitor that elicits its anti-biofilm activity through nontoxic means as well as providing the first 2-aminoimidazole with a TAGE scaffold to report an $\mathrm{IC}_{50}$ value in the nanomolar range.

Finally, we looked to see if this TAGE-triazole library was able to demonstrate anti-biofilm activity against Pseudomonas aeruginosa, a Gram-negative, opportunistic bacterium most commonly known for causing morbidity in nearly all those predisposed to the genetic disease that causes cystic fibrosis (CF). This biofilmforming bacterium is also a threat for infection in burn victims as well as those who are immunocompromised. ${ }^{25} P$. aeruginosa is notorious for being multidrug-resistant against many antibiotics as well. There are several mechanisms by which this bacterium evades the action of antimicrobial agents: restricted uptake, multidrug efflux pumps, and the use of chromosomally-encoded antibiotic resistance genes which occur naturally and can be acquired via horizontal gene transfer. ${ }^{26}$

During the course of our studies with $P$. aeruginosa we have observed PAO1 and PA14 to be capable of forming a very dense biofilm at room temperature compared to biofilms formed at $37^{\circ} \mathrm{C}$ (Fig. 9). Based upon this observation we decided to screen the TAGE-triazole library against PAO1 at room temperature. When inhibition screens are carried out at $37^{\circ} \mathrm{C}$, TAGE 8 was reported to inhibit PAO1 biofilm formation giving an $\mathrm{IC}_{50}$ value of $100 \mu \mathrm{M} .{ }^{13}$ DibromoTAGE 7 demonstrated a 50 -fold increase in biofilm inhibition activity against PAO1 $\left(\mathrm{IC}_{50}\right.$ value of $\left.1.77 \mu \mathrm{M}\right)$ compared to TAGE $\mathbf{8} .^{16}$

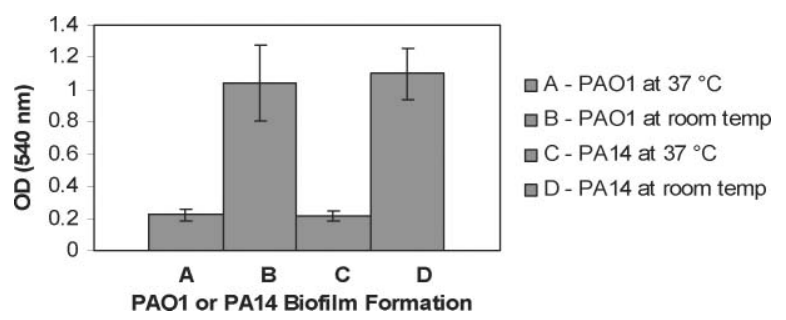

Fig. 9 Quantification of biofilm formation by crystal violet staining of microtiter wells at room temperature and $37^{\circ} \mathrm{C}$.

These small molecules were screened at room temperature to demonstrate the difference temperature has on the inhibition of P. aeruginosa biofilm formation. TAGE 8 and DibromoTAGE 7 gave $\mathrm{IC}_{50}$ values of $361 \pm 9.5 \mu \mathrm{M}$ and $15.8 \pm 0.7 \mu \mathrm{M}$ respectively. This is about a 4- to 8 -fold higher $\mathrm{IC}_{50}$ value then those observed at $37{ }^{\circ} \mathrm{C}$. These values correspond to the increase in biofilm formation at room temperature. Based upon this observation, we screened the library at an initial concentration of $500 \mu \mathrm{M}$ to identify preliminary hits at room temperature. 
Table 4 Biofilm inhibition activity against PAO1 at room temperature

\begin{tabular}{ll}
\hline TAGE-triazole & \% Inhibition at $500 \mu \mathrm{M}$ \\
\hline H3 & $99 \pm 1$ \\
C3 & $96 \pm 1$ \\
P1 & $96 \pm 2$ \\
C4 & $75 \pm 1$ \\
H2 & $62 \pm 5$ \\
H6, P5 & $45 \pm 8$ \\
P3 & $33 \pm 4$ \\
C1 & $28 \pm 9$ \\
P4 & $27 \pm 8$ \\
H4 & $22 \pm 2$ \\
A1 & $20 \pm 5$ \\
P2 & $19 \pm 4$ \\
H1, C5, H7 & $<10$ \\
C2, H5, A2, A3, A4 & No activity \\
\hline
\end{tabular}

The results of the initial screen at $500 \mu \mathrm{M}$ are shown in Table 4. Three members of this library (H3, C3, P1) demonstrated $>95 \%$ inhibitory activity against PAO1 at $500 \mu \mathrm{M}$. A4 demonstrated no inhibition activity at $500 \mu \mathrm{M}$. This was surprising since it closely resembles the structure of DibromoTAGE 7.

We then set out to determine the $\mathrm{IC}_{50}$ value of $\mathbf{H 3}$ against both PAO1 and PA14 with the newly adopted inhibition screen at room temperature to compare this small molecule to TAGE 8 and DibromoTAGE 7. The $\mathrm{IC}_{50}$ values of $\mathbf{H 3}$ were determined to be $98.5 \pm 10.9 \mu \mathrm{M}$ and $60.2 \pm 2.6 \mu \mathrm{M}$ against PAO1 and PA14 respectively.

TAGE-triazole $\mathbf{H 3}$ was also determined to be acting through a non-toxic mechanism by not killing planktonic bacteria as demonstrated by the growth curves of PAO1 and PA14 after 24 hours. The lead TAGE-triazole $\mathbf{H 3}$ demonstrated inhibition potency against PAO1 and PA14 that was an improvement on that of TAGE 8, however, it does not possess biofilm inhibition activity greater than that of DibromoTAGE 7.

\section{Conclusions}

This novel TAGE-triazole library was constructed utilizing the click reaction to generate a chemically diverse library of small molecules from commercially available or easily prepared terminal alkynes. The implementation of this synthetic route has proven to be an effective approach in generating a chemically diverse set of small molecules possessing structural elements of the biologically active marine alkaloid, bromoageliferin, while tuning the activity with structural variations dictated by the terminal alkyne click partner. Several of these TAGE-triazole compounds were shown to be capable of inhibiting the formation of $A$. baumannii, $S$. aureus and $P$. aeruginosa biofilms. TAGE-triazole A4 has demonstrated the most potent inhibitory response reported thus far against S. aureus biofilm formation. Further developments concerning TAGE-triazole small molecules are underway in our labs and will be reported in due course.

\section{Experimental}

\section{Biofilm screening}

TAGE-triazole library members were dissolved in DMSO, filtered through Whatman $13 \mathrm{~mm}$ GD/X syringe filters and stored as either 50 or $100 \mathrm{mM}$ solutions at $-20^{\circ} \mathrm{C}$ until needed for biological study. The DMSO used in these biofilm inhibition screens did not exceed $1 \%$ by volume and had no effect on bacterial growth or biofilm formation. Acinetobacter baumannii and Staphylococcus aureus were purchased from ATCC. Pseudomonas aeruginosa strains PA01 and PA14 were donated by Dr. Daniel Wozniak at Wake Forest University School of Medicine.

A. baumannii (ATCC 19606) was grown in LB media during the course of this study for inhibition assays and analysis of growth curves. S. aureus (ATCC 29213) was grown in Tryptic Soy Broth supplemented with $0.3 \%$ glucose. PAO1 and PA14 utilized LBNS (LB "No Salt") as the media for this study.

\section{Static biofilm inhibition assay}

An overnight culture of bacterial strain was subcultured at an $\mathrm{OD}_{600}$ of 0.01 into the media used depending on bacterial strain. This was pipetted into test tubes along with a predetermined concentration of the compound tested. The contents of the test tubes were then poured into tilted Petri dishes and $100 \mu \mathrm{L}$ of medium, bacteria and compound were then transferred into 96well PVC microtiter plates. These microtiter plates were then covered with a plastic lid, wrapped in Saran wrap and incubated at either room temperature or $37^{\circ} \mathrm{C}$ for 24 hours. After incubation, the medium was discarded and the plates were vigorously washed twice with water. The remaining biofilm that formed during incubation was stained with $100 \mu \mathrm{L}$ of a $0.1 \%$ crystal violet solution and allowed to sit at room temperature for 30 minutes. After 30 minutes, the crystal violet was discarded and washed thoroughly again with water. The remaining crystal violet which stained the biofilm on the inside of the wells was solubilized with $200 \mu \mathrm{L}$ of $95 \%$ ethanol. The quantification of biofilm formation was accomplished by transferring $125 \mu \mathrm{L}$ of the ethanol solution into a polystyrene microtiter dish, which was read by spectrophotometry $\left(A_{540}\right)$. After subtracting the background from each row, a percent inhibition could be calculated by dividing the amount of crystal violet stain in the wells that contained compound by the amount of crystal violet stain in wells that contained bacteria only. Each concentration reported during the course of this study was repeated two to four times with each biofilm inhibition assay being done in 6 or 8 replicates each. The inhibition effectiveness was plotted to generate a 5 to 8 point curve of the percent inhibition of biofilm formation versus the concentration of compound tested. This curve was used to determine $\mathrm{IC}_{50}$ values.

\section{Growth curves}

An overnight culture of bacterial strain was subcultured into its respective media at an $\mathrm{OD}_{600}$ of 0.01 . The inoculated media $(3 \mathrm{ml})$ was added to two test tubes, one that would not be treated, to serve as a control for bacterial growth, and one that would be treated with a member of the TAGE-triazole library at the $\mathrm{IC}_{50}$ value. The test tubes were shaken while incubated and bacterial growth was monitored at 1, 3, 5, 7 and 24 hours. These experiments were done from three different overnight cultures from three different bacterial colonies in single replicate. 
Note: A. baumannii and S. aureus strains were shaken at $200 \mathrm{rpm}$ at $37^{\circ} \mathrm{C}$ in their respective media. PAO1 and PA14 were agitated at $350 \mathrm{rpm}$ at room temperature in LBNS.

\section{Chemistry}

All chemicals and solvents used for the chemical synthesis of the TAGE-triazole library were purchased from commercially available sources and used without further purification. Silica gel was used for column chromatography and was performed with $60 \AA$ mesh standard grade silica gel from Sorbtech. ${ }^{1} \mathrm{H}$ and ${ }^{13} \mathrm{C}$ NMR spectra were preformed using Varian $300 \mathrm{MHz}$ and $400 \mathrm{MHz}$ spectrometers. Chemical shifts are reported in parts per million relative to $\mathrm{CDCl}_{3}(\delta 7.26), \mathrm{CD}_{3} \mathrm{OD}(\delta 4.78$ or 3.31) and DMSO- $d_{6}(\delta 2.50)$ for ${ }^{1} \mathrm{H}$ NMR and relative to $\mathrm{CDCl}_{3}(\delta$ 77.23), $\mathrm{CD}_{3} \mathrm{OD}(\delta 49.51)$ and DMSO- $d_{6}(\delta 39.51)$ for ${ }^{13} \mathrm{C}$ NMR with TMS as an internal standard. High-resolution mass spectra were obtained at the North Carolina State Mass Spectrometry Laboratory for Biotechnology.

trans-2-Amino-trans-4,5-bis(azidomethyl)cyclohexanol. $2.889 \mathrm{~g}$ (13.9 mmol) of epoxide $\mathbf{1 2}$ was added to a stirring solution of aqueous $\mathrm{NH}_{4} \mathrm{OH}(80 \mathrm{ml})$ in a sealed tube. Ammonia-saturated methanol $(80 \mathrm{ml})$ was then added to completely dissolve the starting material. The tube was then sealed and refluxed for 5.5 hours. The reaction was then cooled in an ice bath before removal of the seal. The reaction was then concentrated under vacuum pressure to give a dark yellow residue. The resulting amine was purified by acid-base extraction by adding $5 \% \mathrm{HCl}(\mathrm{aq})$ to the residue. The organic layer was collected and discarded. The acidic aqueous layer was then treated with $10 \% \mathrm{NaOH}(\mathrm{aq})$ until the aqueous layer was basic and the organic layer was collected, dried with sodium sulfate and concentrated to give $3.024 \mathrm{~g}(97 \%$ yield) of a light yellow residue as a free base of the aminoalcohol product. ${ }^{1} \mathrm{H}$ NMR $\left(300 \mathrm{MHz}, \mathrm{CD}_{3} \mathrm{OD}\right) \delta 3.48(\mathrm{~m}, 1 \mathrm{H}), 3.39(\mathrm{~m}$, $4 \mathrm{H}), 3.27$ (m, 4H), 2.74 (bs, 1H), 1.93-1.70 (m, 4H), 1.62-1.45 (m, $2 \mathrm{H}) ;{ }^{13} \mathrm{C}$ NMR $\left(100 \mathrm{MHz}, \mathrm{CD}_{3} \mathrm{OD}\right) \delta 71.9,55.6,55.5,52.5,36.3$, 35.7, 32.4, 31.8; HRMS (ESI) calculated for $\mathrm{C}_{8} \mathrm{H}_{16} \mathrm{~N}_{7} \mathrm{O}\left(\mathrm{MH}^{+}\right)$ 226.1410 , found 226.1409 .

tert - Butyl-trans - 4,5-bis ( azidomethyl ) - 2-hydroxycyclohexylcarbamate. Di-tert-butyl dicarbonate (4.392 g, $20.1 \mathrm{mmol})$ was added to a stirred solution of $3.024 \mathrm{~g}(13.5 \mathrm{mmol})$ of the aminoalcohol product from the previous step in acetone $(50 \mathrm{ml})$ and distilled water $(30 \mathrm{ml})$. Then $4.951 \mathrm{~g}$ of sodium carbonate ( $46.7 \mathrm{mmol}$ ) was added and the reaction was refluxed for 1 hour. The reaction was quenched with brine and upon cooling the reaction was added to a separatory funnel and extracted with ethyl acetate. The organic layer was washed two times with brine and collected. After drying the organic layer with sodium sulfate the organic layer was concentrated to give $4.355 \mathrm{~g}$ (99\% yield) of the Boc-protected aminoalcohol as a yellow oil which required no further purification. ${ }^{1} \mathrm{H}$ NMR $\left(300 \mathrm{MHz}, \mathrm{CDCl}_{3}\right) \delta 4.83$ (bs, $1 \mathrm{H}), 3.76(\mathrm{~m}, 1 \mathrm{H}), 3.61(\mathrm{~m}, 1 \mathrm{H}), 3.44-3.25(\mathrm{~m}, 4 \mathrm{H}) 1.92-1.82(\mathrm{~m}$, 2H), 1.63-1.46 (m, 4H), 1.39 (s, 9H); ${ }^{13} \mathrm{C} \mathrm{NMR}\left(75 \mathrm{MHz}, \mathrm{CD}_{3} \mathrm{Cl}\right)$ $\delta$ 155.9, 79.9, 67.9, 54.4, 54.3, 34.3, 33.7, 31.6, 29.0, 28.4, 27.3; HRMS (ESI) calculated for $\mathrm{C}_{13} \mathrm{H}_{23} \mathrm{~N}_{7} \mathrm{O}_{3} \mathrm{Na}\left(\mathrm{MNa}^{+}\right)$348.1754, found 348.1754 .

tert-Butyl-trans-4,5-bis( azidomethyl)-2-oxocyclohexylcarbamate (15). $404 \mathrm{mg}(1.24 \mathrm{mmol})$ of the Boc-protected aminoal- cohol synthesized in the previous step was dissolved in $12 \mathrm{ml}$ DMF. PDC (2.867 g, $7.63 \mathrm{mmol}$ ) was then added and the reaction was allowed to stir at room temperature for 24 hours. The reaction was quenched with brine and extracted with ethyl acetate. The organic layer was then washed two times with brine. Sodium sulfate was added to dry the organic layer. Then the organic layer was concentrated and purified by flash column chromatography using 5:1 hexanes:ethyl acetate to afford $328 \mathrm{mg}$ ( $81 \%$ yield) of $\mathbf{1 5}$ inseparable epimers as a clear oil. ${ }^{1} \mathrm{H}$ NMR $\left(300 \mathrm{MHz}, \mathrm{CDCl}_{3}\right)$

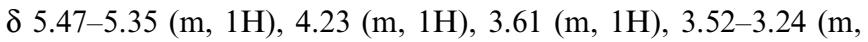
$3 \mathrm{H}), 2.61-2.50(\mathrm{~m}, 1 \mathrm{H}), 2.49-2.34(\mathrm{~m}, 2 \mathrm{H}), 2.09(\mathrm{~m}, 1 \mathrm{H}), 1.94$ $(\mathrm{m}, 1 \mathrm{H}), 1.73-1.68(\mathrm{~m}, 1 \mathrm{H}), 1.43(\mathrm{~s}, 9 \mathrm{H}) ;{ }^{13} \mathrm{C}$ NMR $(75 \mathrm{MHz}$, $\left.\mathrm{CD}_{3} \mathrm{Cl}\right) \delta 205.9,205.2,155.2,79.9,77.4,57.9,55.2,54.1,53.8$, 53.4, 53.1, 43.3, 40.5, 39.5, 38.4, 37.9, 37.0, 34.8, 33.1, 28.4, 28.3, 27.7; HRMS (ESI) calculated for $\mathrm{C}_{13} \mathrm{H}_{21} \mathrm{~N}_{7} \mathrm{O}_{3} \mathrm{Na}\left(\mathrm{MNa}^{+}\right)$ 323.1706 , found 323.1713 .

Azido TAGE (13). To a stirred solution of 15 (437 mg, $1.34 \mathrm{mmol}$ ) in methylene chloride was added $4 \mathrm{ml}$ of TFA dropwise at $0{ }^{\circ} \mathrm{C}$. The reaction continued to stir at $0{ }^{\circ} \mathrm{C}$ for one hour and then was allowed to warm to room temperature for an additional one hour. The reaction was then concentrated and a solution of $\mathrm{HCl}$ in methanol was added and concentrated overnight. Distilled water was added $(8 \mathrm{ml})$ and a $50 \%$ cyanamide solution $(50 \%$ by weight, $500 \mathrm{mg}$ ) was added to the residue and heated to $95{ }^{\circ} \mathrm{C}$ for 2.5 hours. The $\mathrm{pH}$ was 4 for this reaction and required no additional adjustments. The reaction was then allowed to cool and ethanol was added to assist the concentration of this aqueous mixture under high vacuum pressure. It was necessary to wash the residue with ether $(2 \times 150 \mathrm{ml})$ before column chromatography. AzidoTAGE (13) was purified by flash column chromatography using $10 \%$ methanol/ammonia in methylene chloride to afford an orange foam. After 48 hours on a high vacuum pump to remove all residual ammonia, $\mathbf{1 3}$ was then acidified using $\mathrm{HCl}$ in methanol to give $304 \mathrm{mg}\left(79 \%\right.$ yield) as a light yellow foam. ${ }^{1} \mathrm{H}$ NMR (400 MHz, DMSO-d $\left.d_{6}\right) \delta 11.75(\mathrm{~s}, 2 \mathrm{H}), 7.42(\mathrm{~s}, 2 \mathrm{H}), 3.55-3.38$ $(\mathrm{m}, 4 \mathrm{H}), 2.29(\mathrm{~m}, 2 \mathrm{H}), 2.24(\mathrm{~m}, 2 \mathrm{H}), 2.02(\mathrm{~m}, 2 \mathrm{H}) ;{ }^{13} \mathrm{C}$ NMR (100 MHz, $\left.\mathrm{CD}_{3} \mathrm{OD}\right) \delta 148.4,119.8,54.6,36.5,23.2$; HRMS (ESI) calculated for $\mathrm{C}_{9} \mathrm{H}_{14} \mathrm{~N}_{9}\left(\mathrm{MH}^{+}\right)$248.1366, found 248.1365.

\section{General procedure for click reaction}

To a vial with $60-80 \mathrm{mg}$ of AzidoTAGE. $\mathrm{HCl}$ was added $1 \mathrm{ml}$ of ethanol, $1 \mathrm{ml}$ of distilled water and $1 \mathrm{ml}$ of methylene chloride. A stir bar was added and the mixture was stirred to dissolve the starting AzidoTAGE.HCl. Then 6 to 15 equivalents of the predetermined alkyne were added to the reaction mixture. Then 30 to $60 \mathrm{~mol} \%$ of sodium ascorbate relative to the alkyne was added and allowed to dissolve. Finally $\mathrm{CuSO}_{4}$ was added to the reaction mixture and the reaction stirred overnight (1624 hours). The reaction was stopped by adding methanol and transferring to a round bottom flask where the contents were concentrated under high pressure vacuum and the resulting residue was purified by flash column chromatography using 1:15 methanol/ $\mathrm{NH}_{3}$ :methylene chloride as the solvent and increasing the methanol/ $\mathrm{NH}_{3}$ gradually to $1: 4$ until the purified TAGEtriazole analogue was collected as the free base.

(H1.) Butyl TAGE-triazole. ${ }^{1} \mathrm{H}$ NMR (300 $\left.\mathrm{MHz}, \mathrm{CD}_{3} \mathrm{OD}\right) \delta$ $7.70(\mathrm{~s}, 2 \mathrm{H}), 4.42(\mathrm{~m}, 4 \mathrm{H}), 2.69(\mathrm{t}, J=7.2 \mathrm{~Hz}, 6 \mathrm{H}), 2.35-2.21$ 
(m, 4H), 1.64 (quintet, $J=7.5 \mathrm{~Hz}, 4 \mathrm{H}$ ), 1.35 (sextet, $J=7.4 \mathrm{~Hz}$, $4 \mathrm{H}), 0.95$ (t, $J=7.5,6 \mathrm{H}) ;{ }^{13} \mathrm{C}$ NMR (300 MHz, CD $\left.\mathrm{OD}\right) \delta 154.0$, 149.9, 123.7, 120.1, 53.1, 37.2, 32.8, 26.1, 23.3, 21.8, 14.1; HRMS (ESI) calculated for $\mathrm{C}_{21} \mathrm{H}_{33} \mathrm{~N}_{9}\left(\mathrm{MH}^{+}\right)$412.2931, found 412.2930.

(H2.) Pentyl TAGE-triazole. ${ }^{1} \mathrm{H}$ NMR $\left(300 \mathrm{MHz}, \mathrm{CD}_{3} \mathrm{OD}\right) \delta$ $7.71(\mathrm{~s}, 2 \mathrm{H}), 4.44(\mathrm{~m}, 4 \mathrm{H}), 2.68(\mathrm{t}, J=7.8 \mathrm{~Hz}, 6 \mathrm{H}), 2.38(\mathrm{~m}, 2 \mathrm{H})$, $2.28(\mathrm{~s}, 1 \mathrm{H}), 2.23(\mathrm{~s}, 1 \mathrm{H}), 1.64$ (quintet, $J=7.5 \mathrm{~Hz}, 4 \mathrm{H}), 1.33(\mathrm{~m}$, $8 \mathrm{H}), 0.92$ (t, $J=7.1 \mathrm{~Hz}, 6 \mathrm{H}) ;{ }^{13} \mathrm{C}$ NMR (100 MHz, CD $\mathrm{CD}_{3}$ ) $\delta 149.8,149.3,123.8,119.3,52.9,36.9,32.6,30.4,26.4,23.6$, 21.1, 14.5; HRMS (ESI) calculated for $\mathrm{C}_{23} \mathrm{H}_{38} \mathrm{~N}_{9}\left(\mathrm{MH}^{+}\right) 439.3172$, found 439.3162 .

(H3.) Hexyl TAGE-triazole. ${ }^{1} \mathrm{H}$ NMR (300 MHz, $\mathrm{CD}_{3} \mathrm{OD}$ at $4.78 \mathrm{ppm}) \delta 7.63(\mathrm{~s}, 2 \mathrm{H}), 4.37(\mathrm{~m}, 4 \mathrm{H}), 2.61(\mathrm{~m}, 6 \mathrm{H}), 2.28(\mathrm{~s}, 2 \mathrm{H})$, $2.20(\mathrm{~s}, 1 \mathrm{H}), 2.14(\mathrm{~s}, 1 \mathrm{H}), 1.56(\mathrm{~m}, 4 \mathrm{H}), 1.27(\mathrm{~m}, 12 \mathrm{H}), 0.83(\mathrm{~m}$, $6 \mathrm{H}) ;{ }^{13} \mathrm{C}$ NMR $\left(75 \mathrm{MHz}, \mathrm{CD}_{3} \mathrm{OD}\right) \delta 151.2,149.7,123.7,122.2$, 53.5, 37.6, 32.8, 30.6, 30.0, 26.5, 23.7, 23.0, 14.4; HRMS (ESI) calculated for $\mathrm{C}_{25} \mathrm{H}_{42} \mathrm{~N}_{9}\left(\mathrm{MH}^{+}\right)$468.3557, found 468.3550.

(H4.) Heptyl TAGE-triazole. ${ }^{1} \mathrm{H}$ NMR (300 $\left.\mathrm{MHz}, \mathrm{CD}_{3} \mathrm{OD}\right)$ $\delta 7.70(\mathrm{~s}, 2 \mathrm{H}), 4.41(\mathrm{~m}, 4 \mathrm{H}), 2.67(\mathrm{~m}, 6 \mathrm{H}), 2.35(\mathrm{~m}, 2 \mathrm{H}), 2.27(\mathrm{~s}$, $1 \mathrm{H}), 2.21(\mathrm{~m}, 1 \mathrm{H}), 1.66(\mathrm{~m}, 4 \mathrm{H}), 1.35-1.30(\mathrm{~m}, 18 \mathrm{H}), 0.90(\mathrm{~m}, 6 \mathrm{H})$; ${ }^{13} \mathrm{C}$ NMR $\left(75 \mathrm{MHz}, \mathrm{CD}_{3} \mathrm{OD}\right) \delta 149.6,124.0,123.9,123.7,53.5$, 37.5, 33.1, 30.7, 30.4, 30.3, 26.4, 23.8, 22.9, 14.6; HRMS (ESI) calculated for $\mathrm{C}_{27} \mathrm{H}_{45} \mathrm{~N}_{9} \mathrm{Na}\left(\mathrm{MNa}^{+}\right) 495.3798$, found 495.3805 .

(H5.) Decyl TAGE-triazole. ${ }^{1} \mathrm{H}$ NMR $\left(300 \mathrm{MHz}, \mathrm{CD}_{3} \mathrm{OD}\right.$ at $4.78 \mathrm{ppm}) \delta 7.61(\mathrm{~s}, 2 \mathrm{H}), 4.35(\mathrm{~m}, 4 \mathrm{H}), 2.60(\mathrm{~m}, 6 \mathrm{H}), 2.25-2.13(\mathrm{~m}$, $4 \mathrm{H}), 1.58(\mathrm{~m}, 4 \mathrm{H}), 1.25(\mathrm{~m}, 28 \mathrm{H}), 0.82(\mathrm{t}, J=6.6,6 \mathrm{H}) ;{ }^{13} \mathrm{C} \mathrm{NMR}$ (75 MHz, $\left.\mathrm{CD}_{3} \mathrm{OD}\right) \delta 151.3,149.7,123.7,122.2,53.5,37.5,33.2$, $30.8,30.8,30.7,30.6,30.5,30.4,26.4,23.8,22.9$, 14.5; HRMS (ESI) calculated for $\mathrm{C}_{33} \mathrm{H}_{58} \mathrm{~N}_{9}\left(\mathrm{MH}^{+}\right)$580.4809, found 580.4806.

(H6.) 3-Methylbutyl TAGE-triazole. ${ }^{1} \mathrm{H}$ NMR (300 MHz, $\mathrm{CD}_{3} \mathrm{OD}$ at $\left.4.78 \mathrm{ppm}\right) \delta 7.58(\mathrm{~s}, 2 \mathrm{H}), 4.29(\mathrm{~m}, 4 \mathrm{H}), 2.56(\mathrm{~m}, 4 \mathrm{H})$, $2.50(\mathrm{~m}, 2 \mathrm{H}), 2.22(\mathrm{~m}, 2 \mathrm{H}), 2.13(\mathrm{~s}, 1 \mathrm{H}), 2.08(\mathrm{~s}, 1 \mathrm{H}), 1.43(\mathrm{~m}, 6 \mathrm{H})$, $0.82(\mathrm{~d}, J=3.0 \mathrm{~Hz}, 12 \mathrm{H}) ;{ }^{13} \mathrm{C}$ NMR $\left(75 \mathrm{MHz}, \mathrm{CD}_{3} \mathrm{OD}\right) \delta 151.1$, 149.8, 123.6, 122.1, 54.9, 54.6, 39.9, 37.6, 36.7, 28.9, 24.4, 22.9; HRMS (ESI) calculated for $\mathrm{C}_{23} \mathrm{H}_{37} \mathrm{~N}_{9}\left(\mathrm{MH}^{+}\right)$439.3172, found 439.3176 .

(H7.) $\boldsymbol{t}$-Butyl TAGE-triazole. ${ }^{1} \mathrm{H} \mathrm{NMR}\left(300 \mathrm{MHz}, \mathrm{CD}_{3} \mathrm{OD}\right.$ at $3.31 \mathrm{ppm}) \delta 7.72(\mathrm{~s}, 2 \mathrm{H}), 4.48-4.34(\mathrm{~m}, 4 \mathrm{H}), 2.68(\mathrm{~m}, 1 \mathrm{H}), 2.63$ $(\mathrm{m}, 1 \mathrm{H}), 2.36(\mathrm{~m}, 2 \mathrm{H}), 2.27(\mathrm{~s}, 1 \mathrm{H}), 2.21(\mathrm{~s}, 1 \mathrm{H}), 1.33(\mathrm{~s}, 18 \mathrm{~s}) ;{ }^{13} \mathrm{C}$ NMR (75 MHz, CD 3 OD) $\delta 159.0,151.0,121.9,121.7,53.4,37.5$, 31.8, 30.8, 22.6; HRMS (ESI) calculated for $\mathrm{C}_{21} \mathrm{H}_{33} \mathrm{~N}_{9} \mathrm{Na}\left(\mathrm{MNa}^{+}\right)$ 434.2751 , found 434.2751 .

(C1.) Cyclopropyl TAGE-triazole. ${ }^{1} \mathrm{H}$ NMR (400 $\mathrm{MHz}$, $\mathrm{CD}_{3} \mathrm{OD}$ at $\left.3.31 \mathrm{ppm}\right) \delta 7.68(\mathrm{~s}, 2 \mathrm{H}), 4.41(\mathrm{~m}, 4 \mathrm{H}), 2.65(\mathrm{~m}, 2 \mathrm{H})$, 2.38-2.22 (m, 4H), $1.96(\mathrm{~m}, 2 \mathrm{H}), 0.96(\mathrm{~m}, 4 \mathrm{H}), 0.77(\mathrm{~m}, 4 \mathrm{H})$; ${ }^{13} \mathrm{C}$ NMR (100 MHz, CD 3 OD) $\delta 151.9,150.4,122.6,121.0,53.3$, 37.2, 22.2, 8.3, 7.4; HRMS (ESI) calculated for $\mathrm{C}_{19} \mathrm{H}_{25} \mathrm{~N}_{9}\left(\mathrm{MNa}^{+}\right)$ 379.2236 , found 379.2233 .

(C2.) Cyclopentyl TAGE-triazole. ${ }^{1} \mathrm{H}$ NMR $(300 \mathrm{MHz}$, $\mathrm{CD}_{3} \mathrm{OD}$ at $\left.4.78 \mathrm{ppm}\right) \delta 7.60(\mathrm{~s}, 2 \mathrm{H}), 4.39-4.22(\mathrm{~m}, 4 \mathrm{H}), 3.04$ $(\mathrm{m}, 2 \mathrm{H}), 2.55(\mathrm{~m}, 2 \mathrm{H}), 2.24(\mathrm{bm}, 2 \mathrm{H}), 2.16(\mathrm{~m}, 1 \mathrm{H}), 2.11(\mathrm{~m}$, 1H), 2.01-1.94 (m, 4H), 1.74-1.52 (m, 12H); ${ }^{13} \mathrm{C} \mathrm{NMR}(75 \mathrm{MHz}$, $\left.\mathrm{CD}_{3} \mathrm{OD}\right) \delta 154.0,151.1,122.7,122.0,53.5,38.0,37.5,34.3,26.2$, 22.9; HRMS (ESI) calculated for $\mathrm{C}_{23} \mathrm{H}_{33} \mathrm{~N}_{9} \mathrm{Na}\left(\mathrm{MNa}^{+}\right) 458.2751$, found 458.2749 .
(C3.) Cyclohexyl TAGE-triazole. ${ }^{1} \mathrm{H}$ NMR (300 $\mathrm{MHz}$, $\mathrm{CD}_{3} \mathrm{OD}$ at $\left.3.31 \mathrm{ppm}\right) \delta 7.68(\mathrm{~s}, 2 \mathrm{H}), 4.39(\mathrm{~m}, 4 \mathrm{H}), 2.69-2.64$ (m, 4H), 2.27-2.27 (m, 4H), $1.99(\mathrm{~m}, 4 \mathrm{H}), 1.80(\mathrm{~m}, 6 \mathrm{H}), 1.43(\mathrm{~m}$, $12 \mathrm{H}) ;{ }^{13} \mathrm{C}$ NMR $\left(75 \mathrm{MHz}, \mathrm{CD}_{3} \mathrm{OD}\right) \delta 154.9,122.8,122.7,122.4$, 53.4, 37.4, 36.7, 34.3, 27.4, 27.3, 22.6; HRMS (ESI) calculated for $\mathrm{C}_{25} \mathrm{H}_{38} \mathrm{~N}_{9}\left(\mathrm{MH}^{+}\right)$463.3172, found 463.3164.

(C4.) Methylenecyclopentyl TAGE-triazole. ${ }^{1} \mathrm{H}$ NMR (300 MHz, $\mathrm{CD}_{3} \mathrm{OD}$ at $\left.3.31 \mathrm{ppm}\right) \delta 7.70(\mathrm{~s}, 2 \mathrm{H}), 4.42(\mathrm{~m}, 4 \mathrm{H})$, $2.68(\mathrm{~d}, J=7.2,4 \mathrm{H}), 2.33-2.12(\mathrm{~m}, 6 \mathrm{H}), 1.77-1.53(\mathrm{~m}, 14 \mathrm{H})$, $1.29-1.19(\mathrm{~m}, 4 \mathrm{H}) ;{ }^{13} \mathrm{C}$ NMR (100 MHz, CD $\left.\mathrm{OD}\right) \delta 151.0,149.1$, 124.0, 121.7, 53.4, 41.5, 37.5, 33.5, 32.5, 30.7, 30.6, 27.3, 26.2, 22.7; HRMS (ESI) calculated for $\mathrm{C}_{25} \mathrm{H}_{38} \mathrm{~N}_{9}\left(\mathrm{MH}^{+}\right)$463.3172, found 463.3172 .

(C5.) Methylenecyclohexyl TAGE-triazole. ${ }^{1} \mathrm{H}$ NMR (400 MHz, $\mathrm{CD}_{3} \mathrm{OD}$ at $\left.3.31 \mathrm{ppm}\right) \delta 7.69(\mathrm{~s}, 2 \mathrm{H}), 4.50-4.36(\mathrm{~m}$, $4 \mathrm{H}), 2.65(\mathrm{~m}, 4 \mathrm{H}), 2.56(\mathrm{~d}, J=6.8,2 \mathrm{H}), 2.35-2.24(\mathrm{~m}, 4 \mathrm{H})$, $1.70-1.60(\mathrm{~m}, 10 \mathrm{H}), 1.29-1.21(\mathrm{~m}, 8 \mathrm{H}), 1.01-0.93(\mathrm{~m}, 4 \mathrm{H}) ;{ }^{13} \mathrm{C}$ NMR $\left(100 \mathrm{MHz}, \mathrm{CD}_{3} \mathrm{OD}\right) \delta 151.0,148.1,124.3,121.8,53.4$, 39.6, 37.5, 34.3, 34.2, 27.6, 27.4, 22.8; HRMS (ESI) calculated for $\mathrm{C}_{27} \mathrm{H}_{42} \mathrm{~N}_{9}\left(\mathrm{MH}^{+}\right)$491.3485, found 491.3483.

(P1.) Phenyl TAGE-triazole. ${ }^{1} \mathrm{H}$ NMR (300 MHz, $\mathrm{CD}_{3} \mathrm{OD}$ at $3.31 \mathrm{ppm}) \delta 8.37(\mathrm{~s}, 2 \mathrm{H}), 7.80(\mathrm{~d}, J=5.1,4 \mathrm{H}), 7.43(\mathrm{t}, J=5.7$, $4 \mathrm{H}), 7.36(\mathrm{~m}, 2 \mathrm{H}), 4.60(\mathrm{~m}, 4 \mathrm{H}), 2.80(\mathrm{~m}, 1 \mathrm{H}), 2.75(\mathrm{~m}, 1 \mathrm{H})$, $2.57(\mathrm{~m}, 2 \mathrm{H}), 2.41(\mathrm{~s}, 1 \mathrm{H}), 2.39(\mathrm{~s}, 1 \mathrm{H}) ;{ }^{13} \mathrm{C}$ NMR $(75 \mathrm{MHz}$, $\left.\mathrm{CD}_{3} \mathrm{OD}\right) \delta 149.5,149.2,131.8,130.1,129.6,126.9,122.9,121.7$, 53.3, 37.0, 21.4; HRMS (ESI) calculated for $\mathrm{C}_{25} \mathrm{H}_{26} \mathrm{~N}_{9}\left(\mathrm{MH}^{+}\right)$ 452.2305, found 452.2311 .

(P2.) 4-Methoxyphenyl TAGE-triazole. ${ }^{1} \mathrm{H}$ NMR $(300 \mathrm{MHz}$, $\mathrm{CD}_{3} \mathrm{OD}$ at $\left.3.31 \mathrm{ppm}\right) \delta 8.26(\mathrm{~s}, 2 \mathrm{H}), 7.71(\mathrm{~d}, J=6.3 \mathrm{~Hz}, 4 \mathrm{H})$, $6.98(\mathrm{~d}, J=6.6 \mathrm{~Hz}, 4 \mathrm{H}), 4.57(\mathrm{~m}, 4 \mathrm{H}), 3.83(\mathrm{~s}, 6 \mathrm{H}), 2.78(\mathrm{~m}, 1 \mathrm{H})$, $2.74(\mathrm{~m}, 1 \mathrm{H}), 2.56(\mathrm{~m}, 2 \mathrm{H}), 2.40(\mathrm{~s}, 1 \mathrm{H}) .2 .36(\mathrm{~s}, 1 \mathrm{H}) ;{ }^{13} \mathrm{C} \mathrm{NMR}$ $\left(100 \mathrm{MHz}, \mathrm{DMSO}-d_{6}\right) \delta 162.5,159.0,146.3,126.5,123.2,121.1$, 117.0, 114.3, 55.2, 51.2, 34.8, 19.7; HRMS (ESI) calculated for $\mathrm{C}_{27} \mathrm{H}_{30} \mathrm{~N}_{9} \mathrm{O}_{2}\left(\mathrm{MH}^{+}\right)$512.2516, found 512.2520.

(P3.) Methylphenyl TAGE-triazole. ${ }^{1} \mathrm{H}$ NMR (300 MHz, $\mathrm{CD}_{3} \mathrm{OD}$ at $\left.3.31 \mathrm{ppm}\right) \delta 7.64(\mathrm{~s}, 2 \mathrm{H}), 7.29-7.16(\mathrm{~m}, 10 \mathrm{H}), 4.44-4.31$ $(\mathrm{m}, 4 \mathrm{H}), 4.02(\mathrm{~s}, 4 \mathrm{H}), 2.63(\mathrm{~m}, 1 \mathrm{H}), 2.59(\mathrm{~m}, 1 \mathrm{H}), 2.32(\mathrm{~m}, 2 \mathrm{H})$, $2.22(\mathrm{~s}, 1 \mathrm{H}), 2.18(\mathrm{~s}, 1 \mathrm{H}) ;{ }^{13} \mathrm{C}$ NMR $\left(75 \mathrm{MHz}, \mathrm{CD}_{3} \mathrm{OD}\right) \delta 151.1$, 148.8, 140.6, 129.8, 129.7, 127.7, 124.4, 121.8, 53.5, 37.4, 32.7, 22.6; HRMS (ESI) calculated for $\mathrm{C}_{27} \mathrm{H}_{30} \mathrm{~N}_{9} \mathrm{O}_{2}\left(\mathrm{MH}^{+}\right)$479.2546, found 479.2545 .

(P4.) Ethylphenyl TAGE-triazole. ${ }^{1} \mathrm{H}$ NMR (300 $\mathrm{MHz}$, $\mathrm{CD}_{3} \mathrm{OD}$ at $\left.3.31 \mathrm{ppm}\right) \delta 7.49(\mathrm{~s}, 2 \mathrm{H}), 7.49-7.19(\mathrm{~m}, 4 \mathrm{H}), 7.14$ $(\mathrm{m}, 6 \mathrm{H}), 4.37(\mathrm{~m}, 4 \mathrm{H}), 2.97(\mathrm{~m}, 8 \mathrm{H}), 2.60(\mathrm{~m}, 1 \mathrm{H}), 2.56(\mathrm{~m}$, $1 \mathrm{H}), 2.21-2.16(\mathrm{~m}, 4 \mathrm{H}) ;{ }^{13} \mathrm{C}$ NMR $\left(75 \mathrm{MHz}, \mathrm{CD}_{3} \mathrm{OD}\right) \delta 150.7$, 148.7, 142.4, 129.7, 129.5, 127.3, 124.1, 121.6, 53.3, 37.3, 36.7, 28.3, 22.7; HRMS (ESI) calculated for $\mathrm{C}_{29} \mathrm{H}_{34} \mathrm{~N}_{9}\left(\mathrm{MH}^{+}\right)$508.2931, found 508.2923.

(P5.) Methylenephenoxy TAGE-triazole. ${ }^{1} \mathrm{H}$ NMR $(300 \mathrm{MHz}$, $\mathrm{CD}_{3} \mathrm{OD}$ at $\left.3.31 \mathrm{ppm}\right) \delta 8.00(\mathrm{~s}, 2 \mathrm{H}), 7.26(\mathrm{~m}, 4 \mathrm{H}), 6.99-6.92(\mathrm{~m}$, $6 \mathrm{H}), 5.14(\mathrm{~s}, 4 \mathrm{H}), 4.46(\mathrm{~m}, 4 \mathrm{H}), 2.66(\mathrm{~m}, 2 \mathrm{H}), 2.36(\mathrm{~m}, 2 \mathrm{H}), 2.27$ (s, 1H), $2.23(\mathrm{~s}, 1 \mathrm{H}) ;{ }^{13} \mathrm{C}$ NMR (100 MHz, CD $\left.\mathrm{OD}\right) \delta 165.8$, 164.6, 159.9, 145.5, 130.7, 125.9, 122.5, 116.2, 62.6, 53.6, 37.4, 22.7; HRMS (ESI) calculated for $\mathrm{C}_{27} \mathrm{H}_{28} \mathrm{~N}_{9} \mathrm{O}_{2}\left(\mathrm{MH}^{+}\right)$510.2366, found 510.2347 . 
(A1.) Phenylamide TAGE-triazole. ${ }^{1} \mathrm{H}$ NMR (400 $\mathrm{MHz}$, $\mathrm{CD}_{3} \mathrm{OD}$ at $\left.3.31 \mathrm{ppm}\right) \delta 7.90(\mathrm{~s}, 2 \mathrm{H}), 7.83(\mathrm{~d}, J=7.2,4 \mathrm{H}), 7.50$ $(\mathrm{t}, J=7.4,2 \mathrm{H}), 7.42(\mathrm{t}, J=7.4,4 \mathrm{H}), 4.61(\mathrm{~s}, 4 \mathrm{H}), 4.48-4.34(\mathrm{~m}$, $4 \mathrm{H}), 2.59$ (bm, 2H), 2.36 (bm, 2H), 2.24 (bm, 1H), 2.20 (bm, 1H); ${ }^{13} \mathrm{C}$ NMR (100 MHz, CD $\left.\mathrm{OD}\right) \delta 170.2,150.3,146.8,135.4,133.0$, 129.7, 128.5, 125.0, 120.9, 53.3, 37.2, 36.3, 22.2 HRMS (ESI) calculated for $\mathrm{C}_{29} \mathrm{H}_{32} \mathrm{~N}_{11} \mathrm{O}_{2}\left(\mathrm{MH}^{+}\right)$565.2661, found 565.2661.

(A2.) Pyrrole TAGE-triazole. ${ }^{1} \mathrm{H}$ NMR (300 MHz, $\mathrm{CD}_{3} \mathrm{OD}$ at $3.31 \mathrm{ppm}) \delta 7.86(\mathrm{~s}, 2 \mathrm{H}), 6.90(\mathrm{~s}, 2 \mathrm{H}), 6.82(\mathrm{~d}, J=2.7 \mathrm{~Hz}$, $2 \mathrm{H}), 6.13(\mathrm{t}, J=3.2 \mathrm{~Hz}, 2 \mathrm{H}), 4.56(\mathrm{~s}, 4 \mathrm{H}), 4.46-4.37(\mathrm{~m}, 4 \mathrm{H})$, 2.57 (m, 2H), 2.36 (bm, 2H), 2.25 (bm, 1H), 2.19 (bm, 1H); ${ }^{13} \mathrm{C}$ NMR (75 MHz, CD ${ }_{3}$ OD) $\delta 163.8,149.1,147.3,126.7,125.0,123.4$, 119.2, 112.5, 110.5, 53.0, 36.8, 35.6, 21.2; HRMS (ESI) calculated for $\mathrm{C}_{25} \mathrm{H}_{30} \mathrm{~N}_{13} \mathrm{O}_{2}\left(\mathrm{MH}^{+}\right)$543.2567, found 543.2560.

(A3.) Bromopyrrole TAGE-triazole. ${ }^{1} \mathrm{H}$ NMR (400 MHz, $\mathrm{CD}_{3} \mathrm{OD}$ at $\left.3.31 \mathrm{ppm}\right) \delta 7.91(\mathrm{~s}, 2 \mathrm{H}), 6.93(\mathrm{~s}, 2 \mathrm{H}), 6.81(\mathrm{~s}, 2 \mathrm{H})$, $4.57(\mathrm{~s}, 4 \mathrm{H}), 4.56-4.35(\mathrm{~m}, 4 \mathrm{H}), 2.65$ (bm, 2H), 2.42 (bm, 2H), $2.31(\mathrm{~m}, 1 \mathrm{H}), 2.27(\mathrm{~m}, 1 \mathrm{H}) ;{ }^{13} \mathrm{C}$ NMR (100 MHz, $\left.\mathrm{CD}_{3} \mathrm{OD}\right) \delta$ 162.6, 148.9, 147.1, 127.4, 125.1, 123.2, 119.0, 113.9, 97.7, 53.0, 36.7, 35.7, 21.1; HRMS (ESI) calculated for $\mathrm{C}_{25} \mathrm{H}_{27} \mathrm{~N}_{13} \mathrm{O}_{2} \mathrm{Br}_{2} \mathrm{Na}$ $\left(\mathrm{MNa}^{+}\right) 722.0675$, found 722.0669 .

(A4.) Dibromopyrrole TAGE-triazole. ${ }^{1} \mathrm{H}$ NMR $(400 \mathrm{MHz}$, $\mathrm{CD}_{3} \mathrm{OD}$ at $\left.3.31 \mathrm{ppm}\right) \delta 7.93(\mathrm{~s}, 2 \mathrm{H}), 6.86(\mathrm{~s}, 2 \mathrm{H}), 4.56(\mathrm{~s}, 4 \mathrm{H})$, 4.55-4.40 (m, 4H), 2.65 (m, 2H), 2.41 (bm, 2H), 2.28 (bm, 2H); ${ }^{13} \mathrm{C}$ NMR (100 MHz, CD 3 OD) $\delta 161.8,149.0,147.0,128.7,125.0$, 119.1, 114.9, 106.5, 100.2, 53.0, 36.8, 35.8, 21.2; HRMS (ESI) calculated for $\mathrm{C}_{25} \mathrm{H}_{26} \mathrm{~N}_{13} \mathrm{O}_{2} \mathrm{Br}_{4}\left(\mathrm{MH}^{+}\right)$855.9060, found 855.9035.

$N$-(Prop-2-ynyl)benzamide. This compound has been previously reported. For this study it was synthesized in accordance with the procedure in ref. 27.

\section{General procedure for acylation of propargyl amine with pyrrole derivatives}

Propargyl amine $(300 \mu \mathrm{L})$ was added to a stirring solution of the desired 2-(trichloroacetyl)-pyrrole (0.95 equiv) with $\mathrm{Na}_{2} \mathrm{CO}_{3}$ ( 3 equiv) in methylene chloride at room temperature. The reaction was allowed to run overnight. Brine was then added to quench the reaction and the contents were then transferred to a separatory funnel. Ethyl acetate was used to extract the product and the organic layer was washed with brine $(3 \mathrm{x})$. The organic layers were then combined, dried with sodium sulfate and concentrated. The resulting solid was recrystallized in methylene chloride to give yields of $65-80 \%$. The resulting propargyl amides are characterized below.

$\boldsymbol{N}$-(Prop-2-ynyl)-1 $\boldsymbol{H}$-pyrrole-2-carboxyamide. ${ }^{1} \mathrm{H} \quad$ NMR (400 MHz, $\mathrm{CD}_{3} \mathrm{OD}$ at $\left.3.31 \mathrm{ppm}\right) \delta 6.91(\mathrm{~m}, 1 \mathrm{H}), 6.79(\mathrm{~m}, 1 \mathrm{H})$, $6.16(\mathrm{~m}, 1 \mathrm{H}), 4.09(\mathrm{~d}, J=2.0 \mathrm{~Hz}, 2 \mathrm{H}), 2.56(\mathrm{t}, J=2.2 \mathrm{~Hz}, 1 \mathrm{H})$; ${ }^{13} \mathrm{C}$ NMR (75 MHz, CD 3 OD) $\delta 163.5,126.6,123.3,112.2,110.4$, 81.2, 72.0, 29.4; HRMS (ESI) calculated for $\mathrm{C}_{8} \mathrm{H}_{9} \mathrm{~N}_{2} \mathrm{O}\left(\mathrm{MH}^{+}\right)$ 149.0709, found 149.0708.

4-Bromo- $\boldsymbol{N}$-(prop-2-ynyl)-1 $\boldsymbol{H}$-pyrrole-2-carboxyamide. $\quad{ }^{1} \mathrm{H}$ NMR (300 MHz, CD 3 OD at $3.31 \mathrm{ppm}) \delta 6.92(\mathrm{~s}, 1 \mathrm{H}), 6.78(\mathrm{~s}$, $1 \mathrm{H}), 4.08(\mathrm{~d}, J=2.1 \mathrm{~Hz}, 2 \mathrm{H}), 2.57(\mathrm{t}, J=2.3 \mathrm{~Hz}, 1 \mathrm{H}) ;{ }^{13} \mathrm{C} \mathrm{NMR}$ (75 MHz, $\left.\mathrm{CD}_{3} \mathrm{OD}\right) \delta 162.2,127.3,123.2,113.7,97.6,81.0,72.1$,
29.4; HRMS (ESI) calculated for $\mathrm{C}_{8} \mathrm{H}_{8} \mathrm{~N}_{2} \mathrm{OBr}\left(\mathrm{MH}^{+}\right)$225.9742, found 225.9744 .

4,5-Dibromo- $\boldsymbol{N}$-(prop-2-ynyl)-1 $\boldsymbol{H}$-pyrrole-2-carboxyamide. ${ }^{1} \mathrm{H}$ NMR (400 MHz, $\mathrm{CD}_{3} \mathrm{OD}$ at $\left.3.31 \mathrm{ppm}\right) \delta 6.82(\mathrm{~s}, 1 \mathrm{H}), 4.08(\mathrm{~d}$, $J=2.4 \mathrm{~Hz}, 2 \mathrm{H}), 2.58(\mathrm{t}, J=2.7 \mathrm{~Hz}, 1 \mathrm{H}) ;{ }^{13} \mathrm{C} \mathrm{NMR}(100 \mathrm{MHz}$, $\left.\mathrm{CD}_{3} \mathrm{OD}\right) \delta 161.4,128.6,114.7,106.6,100.2,80.9,72.2,29.4$; HRMS (ESI) calculated for $\mathrm{C}_{8} \mathrm{H}_{7} \mathrm{~N}_{2} \mathrm{OBr}_{2}\left(\mathrm{MH}^{+}\right) 304.8919$, found 304.8924 .

\section{Acknowledgements}

The authors would like to thank the University of North Carolina General Administration for funding this work.

\section{References}

1 D. J. Musk and P. J. Hergenrother, Curr. Med. Chem., 2006, 13, 2163.

2 R. M. Donlan and J. W. Costerton, Clin. Microbiol. Rev., 2002, 15, 167.

3 A. Adonizio, K.-F. Kong and K. Mathee, Antimicrob. Agents Chemother., 2008, 52, 198.

4 C. M. Waters, W. Lu, J. D. Rabinowitz and B. L. Bassler, J. Bacteriol., 2008, 190, 2527.

5 G. M. Patriquin, E. Banin, C. Gilmour, R. Tuchman, P. E. Greenberg and K. Poole, J. Bacteriol., 2008, 190, 662.

6 T. B. Rasmussen and M. Givskov, Int. J. Med. Microbiol., 2006, 296, 149.

7 G. D. Geske, R. J. Wezeman, A. P. Siegel and H. E. Blackwell, J. Am. Chem. Soc., 2005, 127, 12762.

8 Y. H. Dong and L. H. Zhang, J. Microbiol., 2005, 43, 101.

9 K. H. Nealson, T. Platt and J. W. Hastings, J. Bacteriol., 1970, 104, 313.

10 M. Hentzer, K. Riedel, T. B. Rasmussen, A. Heydorn, J. B. Anderson, M. R. Parsek, S. A. Rice, L. Eberl, S. Molin, N. Hoiby, S. Kjelleberg and M. Givskov, Microbiology (Reading, UK), 2002, 148, 87.

11 J. F. Hu, E. Garo, M. G. Goering, M. Pasmore, H. D. Yoo, T. Esser, J. Sestrich, P. A. Cremin, G. W. Hough, P. Perrone, Y. S. L. Lee, N. T. Le, M. O'Neil-Johnson, J. W. Costerton and G. R. Eldrich, J. Nat. Prod., 2006, 69, 118.

12 L. M. Junker and J. Clardy, Antimicrob. Agents Chemother, 2007, 51, 3582.

13 R. W. Huigens, J. J. Richards, G. Parise, T. E. Ballard, W. Zeng, R. Deora and C. Melander, J. Am. Chem. Soc., 2007, 129, 6966.

14 J. J. Richards, R. W. Huigens, T. E. Ballard, A. Basso, J. Cavanagh and C. Melander, Chem. Commun., 2008, 14, 1698.

15 J. J. Richards, T. E. Ballard and C. Melander, Org. Biomol. Chem., 2008, 6, 1356.

16 R. W. Huigens, L. Ma, C. Gambino, P. D. R. Moeller, A. Basso, J. Cavanagh, D. J. Wozniak and C. Melander, Mol. Biosyst., 2008, 4, 614.

17 J. J. Richards, T. E. Ballard, R. W. Huigens and C. Melander, ChemBioChem, 2008, 9, 1267.

18 S. A. Rogers and C. Melander, Angew. Chem., Int. Ed., 2008, 47, 5229.

19 J. J. Richards, C. S. Reed and C. Melander, Bioorg. Med. Chem. Lett., 2008, 18, 4325

20 A. Yamada, H. Kitamura, K. Yamaguchi, S. Fukuzawa, C. Kamijima, K. Yazawa, M. Kuramoto, G. Y. S. Wang, Y. Fujitani and D. B. Uemura, Chem. Soc. Jpn., 1997, 70, 3061.

21 M. E. Falagas, P. K. Koletsi and I. A. Bliziotis, J. Med. Microbiol., $2006, \mathbf{5 5}, 1619$

22 S. Shelburn, K. Singh, C. White, L. Byrne, A. Carmer, C. Austin, E. Graviss, C. Stager, B. Murray and R. Atmar, J. Clin. Microbiol., 2008, 46, 198.

23 J. S. Hawley, C. K. Murray, M. E. Griffith, M. L. McElmeel, L. C. Fulcher, D. R. Hospenthal and J. H. Jorgensen, Antimicrob. Agents Chemother., 2007, 51, 376.

24 F. Menichetti, Clin. Microbiol. Infect., 2005, 11, 22.

25 J. W. Costerton, P. S. Stewart and E. P. Greenberg, Science, 1999, 284, 1318.

26 P. A. Lambert, J. R. Soc. Med., 2002, 95, 22.

27 P. Wipf, Y. Aoyama and T. E. Benedum, Org. Lett., 2004, 6, 3593. 